\title{
Exploitation and Protection of Biological Resources in Deep Seabed Areas beyond National Jurisdiction: China's Legislation and Practice
}

\section{Deyi Ma*}

On February 26, 2016, PRC Law on the Exploration and Development of Resources in Deep Seabed Areas was adopted. As a landmark marine legislation, this law was formulated in line with the UNCLOS, the Rules of the International Seabed Authority, and the PRC Constitution. It opened a brand new era of marine development and utilization for China under the strategic background of maritime power. Facing the limitation and challenges about the ecosystem and risk prevention brought about by the UNCLOS and the Convention on Biological Diversity 1992, the maritime powers around the world, including China, have been making domestic legislation on the exploitation and protection of seabed resources beyond national jurisdiction. This paper introduces China's policy for the exploitation and development of the 'Areas' in accordance with the UNCLOS, and makes a further interpretation on China's related domestic legislations and practice.

\section{Keywords}

Deep Seabed Areas, Beyond National Jurisdiction, Common Heritage of Mankind, Biological Resources, Chinese Legislation

\footnotetext{
Professor of Law at East China University of Political Science and Law (ECUPL), China. LL.M. / Ph.D.(Dalian Maritime Univ.). ORCID: http://orcid.org/0000-0001-5093-8177. This research is supported by Shanghai Planning Office of Philosophy and Social Science (2015BFX003) and the National Rule of Law and Law Theory Research Project from Ministry of Justice of the Peoples' Republic of China (16SFB1007). The author would like to thank Prof. Eric Y.J. Lee for his insightful advice. All errors and omissions remain his own. The author may be contacted at: madeyi9@aliyun.com/Address: International Law School, East China University of Political Science and Law, No. 1575 Wanghangdu Road, Shanghai, P.R. China 200042. DOI: http://dx.doi.org/10.14330/jeail.2018.11.1.07
} 


\section{Introduction}

Nowadays, more States begin to realize that the exploration and development of deep seabed resources will be an important source of national economic growth in the future. ${ }^{1}$ In particular, those maritime powers consider the exploration and development of deep seabed as one of the priority targets of their national strategies. Accordingly, it is strongly supposed that major world powers will be exploiting deep seabed resources in the near future. ${ }^{2}$ While attaching great importance to the exploitation activities of deep seabed resources, however, most States has paid little attention to the domestic legislation for those activities. As a result, such domestic legislation is indeed a relatively blank field in most States, including maritime powers.

Against this backdrop, on February 26 2016, the Law of the People's Republic of China on the Exploration and Development of Resources in Deep Seabed Areas (hereinafter Chinese Deep Seabed Law) was adopted at the Nineteenth Session of the Standing Committee of the Twelfth National People's Congress of the People's Republic of China. ${ }^{3}$ The Chinese Deep Seabed Law will greatly enhance and promote the sustainable development of deep seabed area (hereinafter the Area) including the development of marine scientific research, resources survey, resources exploration and exploitation as well as the protection of marine environment of 'the Area.' This law is a landmark domestic marine legislation of China in line with the United Nations Convention on the Law of the Sea 1982 ("UNCLOS"), Rules of the

1 Many domestic laws about the deep seabed resource management and exploration have been adopted in about 15 countries around the world such as, e.g.,: Britain: Deep Sea Mining Act (2014); Fiji: International Seabed Mineral Management Decree (2013);Germany: Seabed Mining Act (2010); Czech Republic: Prospecting, Exploration for and Exploitation of mineral Resources from the Seabed beyond Limits of National Jurisdiction(2000); Cook Islands: Seabed Minerals Acts (2009); US: Deep Seabed Hard Mineral Resources Act (1980); France: Law on Exploration and development of Mineral Resources of the Deep Seabed (1980); Japan: Act on Interim Measures for Deep Seabed Mining (1982). For details, see Zitai Zhang et al., Exploration and Development of Resources in Deep Seabed Areas [深海海底资源勘探开发法研究] (2015), available at http://www.fudanpress.com/showdetail.asp?bookid=10334 (last visited on Apr. 9, 2018).

2 Huai Liu, 10 Research on Development of Overseas DeEp Ocean Technologies, Ships \& Yachts [国外深海技术发展 研究] 7 (2006).

3 PRC Law on the Exploration and Development of Resources in Deep Seabed Areas [中华人民共和国深海海底区域 资源勘探开发法], available at http://www.lawinfochina.com/display.aspx?id=21713\&lib=law (last visited on Apr. 22, 2018). It was adopted on Feb. 26, 2016; entered into force on May 1, 2016. In fact, this is the first Chinese legislation specially dedicated to the "deep seabed area" beyond the national jurisdiction.

4 UNCLOS 1982, 1833 U.N.T.S. 3, available at http://www.un.org/depts/los/convention_agreements/texts/unclos/ unclos_e.pdf (last visited on Apr. 29, 2018). 
International Sea-bed Authority ("ISBA") as well as the Constitution of the People's Republic of China. In addition, the promulgation of the Chinese Deep Seabed Law opens a new era, which is to achieve the strategy of "building China into a marine power." By standardizing economic, social and legal responsibilities of the domestic enterprises, the Chinese Deep Seabed Law provides effective legal norms for the exploration and development of deep-sea biological resources, as well as legal framework for international cooperation.

The China Ocean Mineral Resources R\&D Association was legally entitled to explore the polymetallic nodules in North-East Pacific region in 2001, the polymetallic sulfide deposit in the South-West Indian Ocean exclusively in 2011, and the cobaltrich crusts in the Western Pacific in 2013. ${ }^{7}$ Since then, China has become the first country that owns the exploration right in all the three major international deep seabed resources. In order to (1) promote the deep sea scientific and technological research resources investigation, (2) protect the marine environment, (3) enhance the sustainable utilization of resources in deep seabed areas, and (4) protect the common interests of mankind, it is urgent for China to develop a comprehensive domestic legal system to secure the related activities in the field of exploration and exploitation of deep seabed areas. ${ }^{8}$ Hitherto, 56 proposals submitted by China have been admitted by Sub-Committee on Undersea Feature Names ("SCUFN") and were accordingly included in the list of International Undersea Feature Names. Some of the naming approaches for the Chinese oceanic seabed geographical entities strongly reflect Chinese ideas of Feng (风), Ya (雅) and Song (颂), originated from an anthology of ancient Chinese poetry, THE BoOK OF SONGs. ${ }^{9}$

The primary purpose of this research is to introduce China's policy for the exploitation and development of 'the Area' in accordance with the UNCLOS and make a further interpretation on China's related domestic legislations and practice. This paper is composed of five parts including Introduction and Conclusion. Part two

5 ISBA, available at https://www.isa.org.jm (last visited on Apr. 22, 2018).

6 The strategy of "building China into a marine power" was first proposed to the Eighteenth National Congress of the Communist Party of China on Nov. 8, 2012. See The Report to the Eighteenth National Congress of the Communist Party of China [胡锦涛在中国共产党第十八次全国代表大会上的报告], cpg.people.com.cn, Nov. 8, 2012, available at http://cpc.people.com.cn/n/2012/1118/c64094-19612151.html (last visited on Apr. 29, 2018).

7 China Ocean Mineral Resources R \& D Association [中国大洋矿产资源研究开发协会] was founded and approved by the State Council on April 9, 1990. For details, see the official website of China Ocean Mineral Resources R\&D Association, available at: http://www.comra.org/node_539540.htm (last visited on Apr. 22, 2018).

8 In fact, China became the world's first country getting all the three major exploration rights of mining area resources of the international seabed after the three applications have been respectively approved by the UN in 2001, 2011, and 2013.

9 Book of SONGS (BOOK OF Odes OR CLASSic OF POETRY), available at http://library.umac.mo/ebooks/b26028499.pdf (last visited on Apr. 22, 2018). 
will tackle legal issue on the development of deep seabed resources. Part three will discuss the question of the common heritage of mankind in the course of deep seabed development. Part four will search for China's strategies for biological resources in 'the Area.'

\section{Legal Questions on the Development of Deep Seabed Resources}

\section{A. Whether Biological Resources in 'the Area' is Regulated by Part XI of the UNCLOS?}

On August 17, 1967, during the 22nd Session at the First Committee of the United Nations General Assembly ("UNGA"), Malta's ambassador to the United Nations, Arvid Pardo, proposed a recommendation concerning the establishment of a specialized legal institution for adjusting and regulating the management of the seabed and ocean floors beyond any national jurisdiction, excluding those areas from the national occupation or the regime of the high seas. ${ }^{10}$ The proposal that consider the seabed and ocean floors beyond national jurisdiction as a new development area was later endorsed by the UNGA and drafters of the UNCLOS after a long period of deliberation. Accordingly, the regime of the high seas and the regulation of the Area' has been established beyond any national jurisdiction. ${ }^{11}$ In 1994, the UNGA adopted the Agreement relating to the Implementation of Part XI to the UNCLOS (hereinafter Implementation Agreement). ${ }^{12}$ However, the human's recognition of 'seabed resources' beyond national jurisdiction used to be limited within the range of seabed mineral resources especially during drafting and negotiation for the UNCLOS from 1973 to $1982 .{ }^{13}$ Therefore, in the light of the existing legal provisions and perspective of literal interpretation, the exploitation and conservation of deep seabed biological resources beyond the national jurisdiction should not be included among the provisions of 'the Area' in the UNLCOS.

10 U.N. Doc. A/6695 (July 18, 1967).

1 UNCLOS pt. XI.

12 Agreement relating to the Implementation of Part XI of the United Nations Convention on the Law of the Sea, adopted on July 28, 1994; entered into force on July 28, 1996, available at http://www.un.org/Depts/los/convention agreements/texts/unclos/closindxAgree.htm (last visited on Apr. 9, 2018).

13 Lihai Zhao, Common Heritage of Mankind : An Important principle of Contemporary International Law [“人类的共 同继承财产” 是当代国际法的一项重要原则], 3 J. PEKING U. (Social Science Edition) 北京大学学报(社会科学版) 76-84 (1987). 
'The Area,' as a distinctive maritime zone under Part XI of the UNCLOS, is defined as: "the seabed and ocean floor and subsoil thereof, beyond the limits of national jurisdiction." When laying down the institution of 'the Area,' the UNCLOS also points out that the exploitation and conservation of deep seabed biological resources beyond the national jurisdiction should not be applied in the scope of 'high seas. $^{15}$

\section{B. Limitations of the Convention on Biological Diversity regarding Biological Resources in 'the Area'}

Concerning the ecosystem and risk prevention, the related provisions in Convention on Biological Diversity 1992 ("CBD") ${ }^{16}$ is significant to the legal mechanism of exploration and preservation of biological resources in 'the Area."17 "As described in the note by the Executive Secretary on the subject, the ecosystem approach is a strategy for integrated management of land, water and living resources that promotes conservation and sustainable use of biodiversity in an equitable way." "18 The preamble to the CBD elaborates: "Noting also that where there is a threat of significant reduction or loss of biological diversity, lack of full scientific certainty should not be used as a reason for postponing measures to avoid or minimize such a threat." "It further indicates that "the fundamental requirement for the conservation of biological diversity is the in-situ conservation of ecosystems and natural habitats and the maintenance and recovery of viable populations of species in their natural surroundings. ${ }^{20}$ Nonetheless, the major problems of CBD can be summarized as:

1. Limitation of the applicability. According to Article 4 of the CBD, it is applicable to not only the biotic components, but also the activities and processes which are harmful to ecosystem in the areas within the national jurisdiction. However, with respect to the areas beyond the national jurisdiction, the CBD is only enforceable to activities and processes conducted under the control or the jurisdiction of contracting parties.

14 UNCLOS art $1.1(1)$.

15 Id. art. 133.

161760 U.N.T.S. 79, adopted on June 1, 1992; entered into force on Dec. 29, 1993.

$17 \mathrm{UNEP} / \mathrm{CBD} / \mathrm{SBSTTA} / 5 / 11$, available at https://www.cbd.int/doc/meetings/sbstta/sbstta-05/official/sbstta-05-11-en.pdf (last visited on Apr. 22, 2018).

18 Marine and Coastal Biological Diversity, COP 6, UNEP/CBD/COP/DEC/VII/11, at 4, available at https://www.cbd. int/doc/decisions/cop-07/cop-07-dec-11-en.pdf (last visited on Apr. 22, 2018).

19 Id. COP 10. See also CBD, pmbl., ๆ 9, available at https://www.cbd.int/convention/articles/default.shtml?a=cbd-00 (last visited on Apr. 22, 2018).

20 CBD pmbl., $\uparrow 10$. 
2. Focus on the protection of terrestrial biological diversity. Although the CBD is applicable to both land and marine areas, its main emphasis of regulation still focuses on land areas. What's more, little is mentioned about the specific rights and obligations on the development and conservation of resources beyond national jurisdictions, only limited to those principle regulations. ${ }^{21}$

\section{The Principle of Common Heritage of Mankind: Dilemma and Solutions}

\section{A. Controversy over the Concept of "Common Heritage of Mankind"}

Ever since the concept "common heritage of mankind"22 first emerged, developed and developing countries have been differ in interpreting this concept, due to their different interest in pursuing marine resources. It reflects that every State endeavors to pursue for more shares of the marine resources beyond national jurisdiction by utilizing their distinct interpretation of the principle of "common heritage of mankind."23

Therefore, in order to avoid the harsh competition in the exploitation in the seabed and to set reasonable restrictions on the exploitation of the seabed by technologically advanced States, most developing countries strongly advocate the principle of "common heritage of mankind" for 'the Area' as an international institution which should be covered, managed and supervised by an international body. ${ }^{24}$ By adopting this 'internationalized' approach, developing countries may claim to share more benefits from 'the Area.' On the contrary, developed countries denied the legal status of the "common heritage of mankind" principle and claimed the biological resources in 'the Area' to be under the principle of the "Freedom of the High Seas." 25 According to the arguments of developed countries, the biological resources in 'the Area' should

21 'Biodiversity' refers to "the variability among living organisms from all sources including, inter alia, terrestrial, marine and other aquatic ecosystems and the ecological complexes of which they are part; this includes diversity within species, between species and of ecosystems." See CBD art. 2, available at https://www.cbd.int/convention/articles/ default.shtml? $\mathrm{a}=\mathrm{cbd}-02$ (last visited on Apr. 22, 2018).

22 G.A. Res. 2340(XXII), U.N. Doc. A/RES/2340(XXII), available at http://www.un.org/en/ga/search/view_doc. asp?symbol=A/RES/2340(XXII) (last visited on Apr. 22, 2018).

23 J. Swind, Who will Own the Ocean, 4 Foreign Aff. 356 (1970).

24 Qi Muni, New Ocean Policy : Fantasy and Reality, 22 J. Indian InT'L L. 88 (1982). See also W. Lissner, Mankind's Common Heritage, 37 Ам. J. Econ. \& Sociology, 69-70 (1978), available at https://onlinelibrary.wiley.com/doi/ abs/10.1111/j.1536-7150.1978.tb02796.x (last visited on Apr. 23, 2018).

$25 \mathrm{Yu}$ Fu, The United States and United Nations Convention on the Law of the Sea, 8 PAC. J. 88-95 (2010). 
be fairly open to every country and individual in terms of the rights for exploration and development. ${ }^{26}$

As regard the contents and nature of the "common heritage of mankind," some scholars suggest that the concept lacks the accuracy or legal connotation, ${ }^{27}$ while others argue that it should be associated with such terminologies as "common heritage' or "res commons of human beings." Hence, "common heritage of mankind" should be regarded as the expansion of traditional principle of 'res commons' which reflect the principle of equity and justice in a higher level. ${ }^{28}$

\section{B. Challenges to the Principle of the "Common Heritage of Mankind"}

Beginning with the 1990s, the drastic changes in global politics and economy severely hit Eastern Europe. In this course, the international community realized that the exploitation of the international seabed resources would not be achieved smoothly in a relatively short period of time without the active participation and engagement of major developed countries. ${ }^{29}$ The UNGA resolution 46/78 on the law of the sea not[ed]: "the progress being made by the preparatory commission for the International Seabed Authority and for the International Tribunal for the Law of the Sea in all areas of its works., 30

Thereafter, in July 1994, the Implementation Agreement was adopted at the Fortyeighth Session of the General Assembly. ${ }^{31}$ This Implementation Agreement makes some substantial modifications to the original provisions in Part XI of the UNCLOS, such as the resolutions of ISBA; the review conference; the technology transfer and production policies. They mainly affirm the rights of developed countries and reduce the obligation of patent technology transfer. Annex 1 shows the modifications in the Agreement on Part XI of the UNCLOS. Such new version on the regime of 'the Area' tried to effectively reduce the conflicts of interest concerning the resources development there between the developed and developing countries, thereby facilitating the general acceptance of the UNCLOS by the developed countries.

Nevertheless, the developing countries actually made another concession to the

26 Zhao, supra note 13, at 76-84.

27 R. Anand, Common Heritage of mankind: Multilation of an Ideal, Indian J. InT'L L. 11 (1997).

28 A. Kiss, La Notion de Patrimoine Commun De L'humanité [Notion of Common Human Inheritance], 175 RECUEIL DES COURS 120-3 (1982).

29 For details, see PRC State Oceanic Administration Department of International Cooperation, InTERNATIONAL SEABED MATERIALS [国家海洋局国际合作司:《国际海底资料》] 4 (1995).

30 U.N. Doc. A/RES/46/78 (Dec. 12, 1991), ๆ 9, available at http://www.un.org/documents/ga/res/46/a46r078.htm (last visited on Apr. 9, 2018).

31 Supra note 12. 
developed countries towards the "common heritage of mankind" in the following three points. First, the obligations of contracting parities and their enterprises have been relieved considerably. In fact, as the exploration of seabed resources turns out to be more market-dominant, the provisions concerning the 'Plan' referred to in Article 160 of the UNCLOS has been weakened. ${ }^{32}$ Contractors of developing activities could enjoy sufficient freedom, while maintaining a stable contractual relationship with the ISBA simultaneously. If contracting parties no longer bear any liabilities of providing funds, sharing and transferring technologies will be determined by the market elements because the acquisition level of such technologies. Second, the Enterprise Apartment of the Authority was abolished. ${ }^{33}$ Third, the US' permanent membership of the council was expressly stipulated. ${ }^{34}$ It provides:

The general policies of the Authority should be formulated by the common participation of both the General Assembly and the Council." ... "The General Assembly should make the resolutions according to the recommendation of the Council if the resolution involves any administrative, budgetary and financial affairs covered by the jurisdiction of the Council. ${ }^{35}$

The Implementation Agreement indicates that the substantive rights originally granted to the Authority have been transferred to the council comprising of the minority of member States. ${ }^{36}$

32 J. Duff, UNCLOS and the New Deep Seabed Mining Regime: the Risk of Refuting the Treaty, 19 SufFolk TranSNAT'L L. Rev. 10-7 (1995).

33 Regulations on Prospecting and Exploration for Poly-Metallic Sulphides in 'the Area,' arts. 16 \& 19, available at https:/www.isa.org.jm/files/documents/EN/Regs/PolymetallicSulphides.pdf (last visited on Apr. 22, 2018).

34 Yong Zhou, Dilemma and reasons for the Common Human Inheritance Principle of National Seabed, 1 INT'L F. 8-10 (2012).

35 Regulations on Prospecting and Exploration for Cobalt-rich Ferromanganese Crusts in 'the Area,' ISBA/16/C/WP.2 (Nov. 29, 2009), available at https://www.isa.org.jm/sites/default/files/files/documents/isba-16c-wp2_4.pdf (last visit on Apr. 9, 2018).

36 Annex of the Implementation Agreement to Part XI of the UNCLOS, arts. 1 \& 5, available at http://www.un.org/ Depts/los/convention_agreements/texts/unclos/closindx.htm (last visited on Apr. 21, 2018). 


\title{
4. China's Strategies Governing Biological Resources of 'the Area'
}

\section{A. China's Entitlement to the Exploitation of Biological Resources in 'the Area'}

Since the year of 2000, China has been conducting and approving the research projects on deep-sea creatures and genetic resources. In addition, the Third Institute of Oceanography State Oceanic Administration of PRC was set up as the Research and Development Base for marine biological resources. ${ }^{37}$ In 2003, China announced to establish the first deep-sea microbial resources library. In 2005, the Marine Culture Collection of China ("MCCC") were proclaimed to be established for mega data covering coastal waters of both China and other maritime areas in the world, as well as the biodiversity environment in deep seabed of North and South Pole. ${ }^{38}$ Liu and Zhu said:

\begin{abstract}
Then, in 2011, the MOST of PRC decided to operate the national infrastructure of marine microbial resource for shared services whose purpose was to share information on a symbiotic marine microbial resources. It was assigned to sampling, researching and restoring the resource for world community, as well as conducting marine microbial resource research and development as an institution of marine culture collection for commonweal. ${ }^{39}$
\end{abstract}

Between 2005 and 2012, the number of research papers concerning the deep-sea microbial species in China increased rapidly. China is certainly building scientific research teams specialized in bio-prospecting of seabed biological resources.

\section{B. The Development of China's Technology on Exploration and Exploitation in 'the Area'}

Recently, the research and development on bathyscaphe has been rapidly progressing. As a result, China achieved several breakthrough improvements. As mentioned

37 See the official website of the PRC Third Institute of Oceanography State Oceanic Administration, available at http:// www.tio.org.cn (last visited on Apr. 21, 2018).

38 For details on MCCC, see Ruirui Liu \& Wenli Zhu, Interview with Shao Zongze, Director of the State Oceanic Administration Key Laboratory of Marine Biological Genetic Resources [浮天沧海远 犹有科研人-访国家海洋局 海洋生物遗传资源重点实验室主任邵宗泽], 7 SCIENTIFIC CHINESE [科学中国人] 40-2 (2012).

39 Id. 
above, in June 2002, MOST listed the manned deep-sea submersible Jiaolong, (more advanced equipment for exploring and exploiting deep-sea mineral resources) as a Key Project of 10th "Five-Year Plan" in the National High Technology Research and Development Program of China. ${ }^{40}$ In August 2009, the manned deep-dive test (1000 meters in depth) for the submersible Harmony, predecessor of Jiaolong, was firstly carried out in the South China Sea. The successful tests were conducted continuously for 20 times. The maximum depth of the test reached 1109 meters. ${ }^{41}$

Thanks to this success, China became a country operating the manned deep-sea submersible with the depth capacity of 1000 meters together with the US, Russia, Japan and France. In the end of 2009, Harmony was renamed Jiaolong; in July 2010, Jiaolong successfully navigated underwater with the maximum test depth of 3759 meters. ${ }^{42}$ Based on the success in deep-sea exploration vehicles R\&D, China began its active research and investigation on biological resources in 'the Area.' With over 40 ocean investigations, especially regarding deep-diving submersible and sample acquisition which gained substantive breakthrough and progress, China has been getting more acquainted with the deep seabed and improving its technology regarding the exploration and utilization of deep sea resources. For example, in 2007, some new sea-floor hydrothermal activity regions were found in ultra-slow spreading ridge of the South-West Indian Ocean ("SWIO"); in 2008, at least five new sea-floor hydrothermal activity regions were discovered by R/V Dayang Yihao in ocean floor along the eastern Pacific equator, where a large number of samples were collected including sulphides chimneys, ferromanganese oxide, hydrothermal vent, sediment and water samples. ${ }^{43}$

Besides, China has completed its self-developed research platform for deepsea microbial resource which covers both field test and laboratory. The second genome high pressure deep-sea microorganism and the first meta genomic DNA of a deep sea sediment were also established in China. ${ }^{44}$ More than 20 new species

40 National High Technology Research and Development Program of China (863 Program), available at http://www. most.gov.cn/kjbgz/201305/t20130502_105668.htm (last visited on Apr. 21, 2018).

41 Liu Tao et al., Present Development Situation and Technological Progress of Deep-sea Submersible [深海载人潜水器 发展现状及技术进展], 53 ShIPBUILDING OF CHINA [中国造船] 233-43 (2012).

42 Qi Yun, Marine Kim Kong, the Deep-sea Submersible [海底金刚-深海载人潜水器], 3 J. UFO RES. [飞碟探索] 40-1 (2011).

43 Qi Lu, China found Seafloor hydrothermal activity in large scale in the eastern Pacific Ocean [我国在东太平洋 首次发现大范围海底热液活动群], SCI. TIMES Oct. 23, 2008, available at http://news.sciencenet.cn/sbhtmlnews/ 2008/10/212011.html?id=212011 (last visit on Apr. 9, 2018).

44 Jiancai Jin, Management on the Biological Diversity and heredity of Deep Seabed Recourses [深海海底生物多样性基 因资源管理问题], 1 AdVANCE IN EARTH SCI. [地球科学进展] 11-8 (2005). 
have been reported and a fresh batch of extremozymes, ${ }^{45}$ tool enzymes ${ }^{46}$ with great commercial and scientific value have been separated. After conducting the research and experiments on natural biopharmaceuticals and antifouling leading compounds, China has finally confirmed and obtained few special biological substances in deepwater environment which provided valuable materials for the development and scientific research in bio-tech industry. ${ }^{47}$

\section{China's Principles on Construction of Deep Seabed Legal Regime}

China is expected to promulgate the regulations and supervision measures concerning the resources development in 'the Area' in the near future. Also, corresponding international law will be developed for exploring international seabed resources. With the rapid progress of science and technology in deep seabed exploration, the natural resources of 'the Area' may bring about great commercial development. China will pay close attention to the related legislation and practice on the global level in a scientific manner for coordination and openness. ${ }^{48}$

\section{Principle of Scientific Development}

The Chinese Deep Seabed Law corresponds to the practical experience of Chinese contractors in the exploration and development of deep seabed resources. In order to promote the harmonious and sustainable development of marine industry, China will take the scientific development, the capacity of marine resources, and environmental protection and sustainable exploitation into consideration. ${ }^{49}$

45 'Extremozymes' is produced by a kind of microorganism which can grow under some extreme environments. It can be used as catalyst and plays an important role in the survival and procreation of extremophiles in severe environments. For details, see K. Dumorné et al., Extremozymes: A Potential Source for Industrial Applications, 27(4) J. MicroBioL. BioteCHNOL. 649-59 (Apr. 28, 2017), available at https://www.ncbi.nlm.nih.gov/pubmed/?term=Dumorn\%C3\%A9\%20 K\%5BAuthor\%5D\&cauthor=true\&cauthor_uid=28104900 (last visited on Apr. 29, 2018).

46 The key technology for genetic engineering is the connection and reorganization of deoxyribonucleic acid (DNA) and during this process, 'enzymes' can be very helpful. For details, see A. Radzicka \& R. Wolfenden, A proficient enzyme, 267 (5194) SCI. 90-3 (Jan. 6, 1995), available at http://science.sciencemag.org/content/267/5194/90 (last visited on Apr. 22, 2018).

47 PRC State Council, The 13th five-year plan for national science and technology innovation, Aug. 8, 2016, available at http://www.gov.cn/zhengce/content/2016-08/08/content_5098072.htm (last visited on Apr. 21, 2018).

48 Zhang Dan \& JiluWu, Research and Analysis on China's Deep Seabed Area Resources Exploration and Exploitation Law [我国首部深海海底区域资源勘探开发法评析] 1:1 CNKI J. BOUNDARY \& OCEAN STUD. [边界与海洋研究] 68 (2016).

49 See Seabed Disputes Chamber of the International Tribunal for the Law, Responsibilities and Obligations of States Sponsoring Persons and Entities with respect to Activities in 'the Area' Advisory Opinion, Feb. 1, 2011, available at https://www.itlos.org/fileadmin/itlos/documents/cases/case_no_17/adv_op_010211.pdf(last visited on Apr. 19, 2018). 


\section{Principle of Coordination}

In the field of exploration and development of deep seabed resources, the domestic law of the UNCLOS parties should be coherent and coordinated with the related rules and regulations formulated by the ISBA. Also, the deep sea-bed laws should actively coordinate the relationship between the procedures of state guarantee on the domestic level, and the signing of the contracts for exploring and developing the resources on the international level. ${ }^{50}$

\section{Principle of Openness}

In recent years, the number of the potential contractors secured by the UNCLOS members has been dramatically increasing, most of whom are making positive and constant efforts to submit their applications for the exploration and development of deep seabed resources to the ISBA. ${ }^{51}$ There is a tendency of diversifying the subjects of the application, which is rapidly booming and developing the exploration and development of deep seabed resources. ${ }^{52}$

\section{Improvement in China's Domestic Legislation on Biological Resources in 'the Area'}

There is no doubt that the domestic legislation of biological resources in 'the Area' can provide specific legal safeguard for the exploitation and utilization of biological resources. It can also play an important role in promoting China's position during the negotiations for drafting international law in this field.

In particular, the Chinese Deep Seabed Law symbolizes that China has accomplished its domestic legislation on deep seabed exploration and exploitation. The law specifies the range of subject and the application procedure for the exploration and exploitation of deep seabed areas, and provides special and concrete regulations to spouse corresponding norms of obligations to contractors. ${ }^{53}$ However, there are some notable omissions and shortcomings in the Chinese Deep Seabed Law. For instance, the law does not explicitly refer to the specific provisions for the exploitation and

50 Zitai Zhang, Thoughts on the Construction of Legal System for Exploration and Developmentof Deep Seabed Resources in China [构建我国深海海底资源勘探开发法律体系的思考], 11 ACADEMIC J. ZHONGZHOU [中州学刊] 53 (2017).

51 Shanbao Zhang, An Analysis of the Legal Attributes of Living Resources in International Seabed Area [国际海底区域 生物资源法律属性探析], 4 CHINESE J. MAR. L. [中国海商法研究] 94-100 (2013).

52 Zitai Zhang et al., Research on the Exploration and Development of Deep Seabed Resources [深海海底资源勘探 开发法研究] 233 (Fudan Univ. Press, 2015).

53 Huirong Liu \& Xiaoxin JI, The Legal Status all Use of Deep-Sea Genetic Resources beyond National Jurisdiction-The Benefits-sharing Based on Intellectual Property, [刘惠荣纪晓昕国家管辖外深海遗传资源的归属与利用-兼析以 知识产权为基础的惠益分享制度], 4 LEGAL F. [法学论坛] 62-6 (2009). 
utilization of biological resources in 'the Area.' Also, Chapter III (Environmental Protection) of the Chinese Deep Seabed Law reinforces the rules of marine environmental protection through clear identification of 'ecosystems,' "critically endangered marine species" and 'marine organisms,' thereby enacting enormous number of laws on 'the Area. ${ }^{54}$

Meanwhile, the Chinese Deep Seabed Law established the licensing system for the exploration and development of mineral resources in 'the Area.' Obviously, the licensing system is the core part of this law. It is well recognized that exploration and development are of extremely high significance in the related activities of mineral resources exploration and development in 'the Area.' Article 27 of the Chinese Deep Seabed Law defines ‘exploration' as:

the search and analysis of resources in deep seabed areas, use and test of resource collection systems and equipment, processing facilities and transport systems, as well as the research on environment, technologies, economy, commerce and other relevant factors that shall be considered at the time of development.

In Article 27, 'development' is also defined as "the recovery and selection of resources in deep seabed areas for business purposes, including the construction and operation of collection, processing and transport systems serving the production and sale of

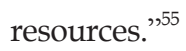

Environmental protection constitutes one of the most important aspects of the Chinese Deep Seabed Law. Generally, the scientific research and resources investigation would not have serious influence on the environment, while the exploration and development might bring relatively negative impacts on the marine environment and even lead to severe environmental pollution or damage towards 'the Area.' As the Chinese Deep Seabed Law attaches great importance to the environmental protection, the related provisions are included not only in Chapter III (environmental protection), but also in other chapters. ${ }^{56}$ If an entity violates the environmental protection regulations in the Chinese Deep Seabed Law and causes pollution or damage to the marine environment, or cultural relics and pavements within the operation area, the Oceanic Administration of the State Council shall order the entity to cease the violation of the law and impose a fine on it. ${ }^{57}$ If any

\footnotetext{
4 Chinese Deep Seabed Law, art. 14.

5 Id. art. 27 (1) \& (2).

6 Id. arts. $1-2 \& 11$.

5 Id. art. 26.
} 
crime is committed, the entity shall be subject to criminal liability in accordance with the law. ${ }^{58}$ Both the contractors and the state tendering the guarantee might take the corresponding responsibilities.

If there is deficiency in the domestic legislation on the exploration and development of deep seabed resources, the Marine Stewardship Council would directly shift the compensation responsibility from its domestic contractors to the state. ${ }^{59}$ To put it another way, without the corresponding legislation, any government would take the responsibility and pay for the illegal exploitative activities carried out by its domestic enterprises. Hence, legislation on exploitation of deep-seabed resources is not only necessary measurement to fulfill the requirements of the UNCLOS, but also indispensable condition to acquire the admission ticket to the exploitation of deep seabed resources. As a result, the Chinese Deep Seabed Law is an absolute legal prerequisite for China to shift its activities from the offshore to 'the Area.' Such legislative activities would develop significant impact on China's national strategy of "gradually becom[ing] a powerful marine country.",60

\section{Conclusion}

Domestic legislation on the exploration and development of resources in 'the Area' beyond national jurisdiction can effectively regulate and standardize the exploitative activities of deep seabed resources, which would direct the economic, social and legal responsibilities of the domestic enterprises. It can provide the legal safeguard for the exploitation of deep seabed resources, offer the legal basis for the participation of Chinese enterprises in the development of deep seabed resources, and supply legal reference to their activities of seeking transnational cooperation.

The Chinese Deep Seabed Law is first legislation specially dedicated to the development of 'the Area' beyond the national jurisdiction. It has established not only licensing system of China for the resources exploration and development there, but also environmental protection, technological advancement, resources investigation, etc. At the same time, the Chinese Deep Seabed Law lays down the

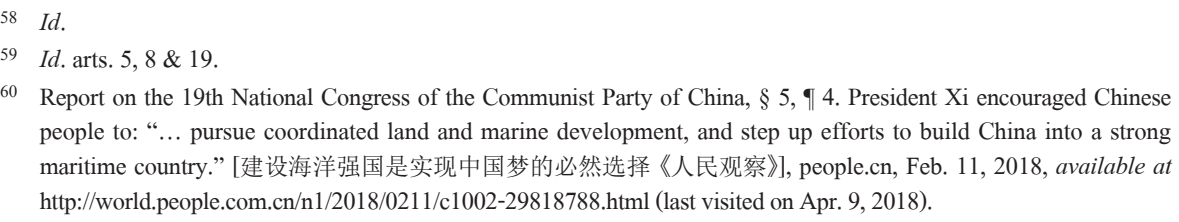

60 Report on the 19th National Congress of the Communist Party of China, § 5, ๆ 4. President Xi encouraged Chinese people to: “... pursue coordinated land and marine development, and step up efforts to build China into a strong maritime country.” [建设海洋强国是实现中国梦的必然选择《人民观察》], people.cn, Feb. 11, 2018, available at http://world.people.com.cn/n1/2018/0211/c1002-29818788.html (last visited on Apr. 9, 2018). 
legal responsibility for the violations, which will improve and promote marine law system of China.

The global maritime powers have been transforming their national strategy from military-orientation to the marine resources development. Deep seabed resources such as petroleum, minerals and genetic resources have become the main objective of scientific research and development in the global society. Because the PRC Mineral Resources Law ${ }^{61}$ and the related legislations about the exploration, development and exploitation of offshore oil are inapplicable to the exploitation of deep seabed resources, the Chinese Deep Seabed Law is the only legal instrument for China to approach to the deep ocean. The Chinese Deep Seabed Law should aim to achieving a dynamic balance between the benefits it brings and the vigilance towards the uncertainty of the international environment over 'the Area.' So, while reflecting its own problems, China should take lessons from the practical experiences of different countries around the world in exploring and developing deep seabed resources. Then, China could remove the possible obstacles on the way to the international exploitation of deep seabed resources.

61 Adopted on Mar. 19, 1986; entered into force on Oct. 1, 1986, available at http://www.gov.cn//ssdjt/content_403851. htm (last visited on Apr. 21, 2018). 
Annex 1: Modifications in the Agreement on Part XI of the UNCLOS

\begin{tabular}{|c|c|c|}
\hline Related Issues & $\begin{array}{l}\text { Specific Positions } \\
\text { in the Agreement }\end{array}$ & Contents in Detail \\
\hline \multirow{2}{*}{$\begin{array}{l}\text { Costs to States } \\
\text { Parties }\end{array}$} & $\begin{array}{l}\text { Annex Section } \\
\text { One: article } 2\end{array}$ & $\begin{array}{l}\text { All organs and subsidiary bodies to be established } \\
\text { under the Convention and this Agreement shall be cost- } \\
\text { effective. This principle shall also apply to the frequency, } \\
\text { duration and scheduling of meetings. }\end{array}$ \\
\hline & $\begin{array}{l}\text { Annex Section } \\
\text { Two: article } 3\end{array}$ & $\begin{array}{l}\text { States Parties shall be under no obligation to finance any } \\
\text { of the operations in any mine site of the Enterprise or } \\
\text { under its joint-venture arrangements }\end{array}$ \\
\hline \multirow{3}{*}{$\begin{array}{l}\text { Institutional } \\
\text { Arrangement }\end{array}$} & $\begin{array}{l}\text { Annex Section } \\
\text { One: article } 3\end{array}$ & $\begin{array}{l}\text { The setting up and the functioning of the organs and } \\
\text { subsidiary bodies of the Authority shall be based on an } \\
\text { evolutionary approach }\end{array}$ \\
\hline & $\begin{array}{l}\text { Annex Section } \\
\text { Two: article } 1\end{array}$ & $\begin{array}{l}\text { The Secretariat of the Authority shall perform the } \\
\text { functions of the Enterprise. (So the establishment of } \\
\text { Enterprise should be postponed) }\end{array}$ \\
\hline & $\begin{array}{l}\text { Annex Section } \\
\text { Nine: article } 1\end{array}$ & $\begin{array}{l}\text { There is hereby established a Finance Committee. The } \\
\text { Committee shall be composed of } 15 \text { members with } \\
\text { appropriate qualifications relevant to financial matters. } \\
\text { (The Finance Committee shall be the subordinate } \\
\text { institute coping with financial issues.) }\end{array}$ \\
\hline \multirow{5}{*}{$\begin{array}{l}\text { Financial } \\
\text { terms of } \\
\text { contracts }\end{array}$} & $\begin{array}{l}\text { Annex Section } \\
\text { Eight: article } 1 \text { (a) }\end{array}$ & $\begin{array}{l}\text { The system of payments to the Authority shall be fair } \\
\text { both to the contractor and to the Authority and shall } \\
\text { provide adequate means of determining compliance by } \\
\text { the contractor with such system }\end{array}$ \\
\hline & $\begin{array}{l}\text { Annex Section } \\
\text { Eight: article } 1(b)\end{array}$ & $\begin{array}{l}\text { The rates of payments under the system shall be within } \\
\text { the range of those prevailing in respect of land-based } \\
\text { mining of the same or similar minerals }\end{array}$ \\
\hline & $\begin{array}{l}\text { Annex Section } \\
\text { Eight: article } 1 \text { (c) }\end{array}$ & $\begin{array}{l}\text { The system should not be complicated and should not } \\
\text { impose major administrative costs on the Authority or on } \\
\text { a contractor. }\end{array}$ \\
\hline & $\begin{array}{l}\text { Annex Section } \\
\text { Eight: article } 1(\mathrm{~d})\end{array}$ & $\begin{array}{l}\text { An annual fixed fee shall be payable from the date of } \\
\text { commencement of commercial production. }\end{array}$ \\
\hline & $\begin{array}{l}\text { Annex Section } \\
\text { Eight: article } 3\end{array}$ & $\begin{array}{l}\text { The fee for processing applications for approval of a } \\
\text { plan of work limited to one phase, either the exploration } \\
\text { phase or the exploitation phase, shall be USD } 250,000 \text {. }\end{array}$ \\
\hline
\end{tabular}




\begin{tabular}{|c|c|c|}
\hline \multirow{4}{*}{$\begin{array}{l}\text { Production } \\
\text { Policy }\end{array}$} & $\begin{array}{l}\text { Annex Section } \\
\text { Six: article } 1 \text { (a) }\end{array}$ & $\begin{array}{l}\text { Development of the resources of the Area shall take place } \\
\text { in accordance with sound commercial principles the } \\
\text { original restriction of } 60 \% \text { of the terrestrial homogeneous } \\
\text { resources exploitation amount was canceled }\end{array}$ \\
\hline & $\begin{array}{l}\text { Annex Section } \\
\text { Six: article } 1(b)\end{array}$ & $\begin{array}{l}\text { The provisions of the General Agreement on Tariffs and } \\
\text { Trade, its relevant codes and successor or superseding } \\
\text { agreements shall apply with respect to activities in the } \\
\text { Area }\end{array}$ \\
\hline & $\begin{array}{l}\text { Annex Section } \\
\text { Six: article } 1 \text { (c) }\end{array}$ & $\begin{array}{l}\text { In particular, there shall be no subsidization of activities } \\
\text { in the Area except as may be permitted under the } \\
\text { agreements referred to in subparagraph (b). Subsidization } \\
\text { for the purpose of these principles shall be defined in } \\
\text { terms of the agreements referred to in subparagraph (b) }\end{array}$ \\
\hline & $\begin{array}{l}\text { Annex Section } \\
\text { Six: article } 1(\mathrm{~d})\end{array}$ & $\begin{array}{l}\text { There shall be no discrimination between minerals } \\
\text { derived from the Area and from other sources }\end{array}$ \\
\hline $\begin{array}{l}\text { Approval of } \\
\text { a plan of work } \\
\text { for exploration }\end{array}$ & $\begin{array}{l}\text { Annex Section } \\
\text { One: article } 7\end{array}$ & $\begin{array}{l}\text { An application for approval of a plan of work shall } \\
\text { be accompanied by an assessment of the potential } \\
\text { environmental impacts of the proposed activities and } \\
\text { by a description of a program for oceanographic and } \\
\text { baseline environmental studies }\end{array}$ \\
\hline \multirow{4}{*}{$\begin{array}{l}\text { Decision- } \\
\text { Making }\end{array}$} & $\begin{array}{l}\text { Annex Section } \\
\text { Three: article } 1\end{array}$ & $\begin{array}{l}\text { The general policies of the Authority shall be established } \\
\text { by the Assembly in collaboration with the Council. }\end{array}$ \\
\hline & $\begin{array}{l}\text { Annex Section } \\
\text { Three: article } 2\end{array}$ & $\begin{array}{l}\text { As a general rule, decision-making in the organs of the } \\
\text { Authority should be by consensus }\end{array}$ \\
\hline & $\begin{array}{l}\text { Annex Section } \\
\text { Three: article } 3\end{array}$ & $\begin{array}{l}\text { Decisions by voting in the Assembly on questions of } \\
\text { procedure shall be taken by a majority of members } \\
\text { present and voting, and decisions on questions of } \\
\text { substance shall be taken by a two-thirds majority of } \\
\text { members present and voting. }\end{array}$ \\
\hline & $\begin{array}{l}\text { Annex Section } \\
\text { Three: article } 15\end{array}$ & $\begin{array}{l}\text { The Council shall consist of } 36 \text { members of the Authority } \\
\text { elected by the Assembly. }\end{array}$ \\
\hline
\end{tabular}


